\title{
Effect of Renovascular Hypertension on to the Ultrastructure of Cardiomyocytes of the Left Ventricle at Different Treatment Options (Experimental Study)
}

\author{
Kateryna Markelova ${ }^{1}$, Olga Lyashchenko ${ }^{2}$, Svetlana Smirnova $^{3}$, Anna Zhukova ${ }^{4}$ \\ ${ }^{1}$ Student of Medical Academy named after S.I. Georgievsky of Vernadsky CFU \\ ${ }^{2} \mathrm{MD}, \mathrm{PhD}$, Associate Professor at the Medical Biology Department of Medical Academy Named After S.I. \\ Georgievsky of Vernadsky CFU \\ ${ }^{3} \mathrm{PhD}$, Associate Professor at the Medical Biology Department of Medical Academy Named After S.I. \\ Georgievsky of Vernadsky CFU \\ ${ }^{4} \mathrm{PhD}$, Assistant at the Medical Biology Department of Medical Academy Named After S.I. Georgievsky of \\ Vernadsky CFU
}

\begin{abstract}
Left-ventricular myocardium was investigated with the electron microscope in normotensive rats with induced arterial hypertension as well as in case of the usage of monotherapy by angiotensin-converting enzyme inhibitors, calcium channel blockers, and the combined action of these drugs. It was established that monotherapy with a calcium channel blocker has a strong positive effect on the myocardium of the left ventricle of animals with induced arterial hypertension (increased number of mitochondria; the number of intercalated disks and the volume of cardiomyocytes were also increased), monotherapy with angiotensin-converting enzyme and the combined effect of above mentioned drugs did not have a positive impact on hypertrophy of the heart muscle.
\end{abstract}

Keywords: electron microscopy, cardiomyocytes, hypertension, correction, rats.

\section{Introduction}

Arterial hypertension (AH) refers to one of the most common syndromes of cardiovascular diseases. One fifth of the world is exposed to $\mathrm{AH}$ and it is one of the main risk factors related to high morbidity and mortality $[1,2,3,4]$. Blood pressure control, especially at the population level, stays low despite the fact that the levels of arterial pressure are easily recorded, and we have effective and safe medical drugs $[5,6,7]$.

Modern treatment concept $\mathrm{AH}$ aims at not only reducing the level of blood pressure, but also decreasing the level of cardiovascular risk $[8,9,10]$. It is known that sufficient treatment helps to reduce disease related complications and increases life expectancy [11]. Regardless of this, the existing pharmacotherapy cannot always prevent development of negative changes in target organs, and occasional occurrence of side effects of the drug, which impairs the effectiveness of treatment of patients with this pathology [12].

The aim of our study was to establish the patterns of ultrastructural features of the myocardium of the left ventricle of normotensive rats under conditions of induced $\mathrm{AH}$ and the possibility of its pharmacological correction.

\section{Materials and Methods}

The experiment was conducted on 40 white rats Wistar, which were kept in standard conditions in the vivarium of the Medical academy named after S.I. Georgievsky according to the rules approved by the European Convention for the protection of vertebrates (Strasbourg, 1986) [13].

The animals that were under observation were divided into the following groups: first group - control group (with induced hypertension without correction); the second group - induced $\mathrm{AH}$ and the correction with the inhibitors of angiotensin converting enzyme (ACE); the third group - induced $\mathrm{AH}$ and usage of the calcium chan- 
nel blockers; the fourth group - induced AH followed by the usage of enzyme inhibitor combined together with calcium channel blockers.

Modeling of arterial hypertension was carried out according to the Grolman method [14]. Correction of arterial hypertension was carried out by intramuscular administration of ACE inhibitors and calcium channel blocker, diluted in saline daily for 2 months since the occurrence of resistant hypertension. Calculation of the dosage of the injected drugs was carried out considering the recommendations of Y. R. and R. S. Rybolovlev [15].

Rats were taken out of the experiment by giving light ether anesthesia followed by decapitation, observing "The rules of the works with experimental animals» [16].

For transmission electron microscopy, the material was processed using standard method [17]. Semi-thin sections $(1 \mu \mathrm{m})$ were made on ultramicrotome UMTP-4 of Sumy production Association "Electron" (Ukraine), painted with methylene blue and viewed in a light microscope for indicative determination of material character. Ultra-thin slices $(30-60 \mathrm{~nm}$ ) manufactured on the same ultratome, contrasted in a saturated solution of uranyl acetate and lead citrate over Reynolds, and analyzed in an electron microscope of the same production association.

\section{Results}

In the first group of the experiment in the myocardium of the left ventricle, compensatory-adaptive and destructive-dystrophic processes were observed. The intercellular space between the cardiomyocytes expanded, the lysis of organelles (primarily of the mitochondria) was noted, the perinuclear space was dilated, the cell nucleus was irregular in shape with scalloped edges. Blood filling of the vessels was increased, but effects of stasis and sludge were not observed.

In the second experimental group, we observed marked hypertrophy of myocardium. Intercalated discs were thicker in comparison with the previous group. The amount of mitochondria was increased. However, the correctness of the ultrastructural organization of myofibrils, intercalated discs, and mitochondria and disrupted $\mathrm{Z}$ discs become tortuous and uneven in thickness.

In the third experimental group, ribosomes accumulated in the sarcoplasm of cardiomyocytes, the granular endoplasmic net and elements of the Golgi apparatus grew in size. This can serve as evidence of activation of the structures that synthesize protein and, as a result can witness the appearance of myocardial hypertrophy. There is an increase in the volume of cardiomyocyte, which is accompanied by the appearance of folding sarcolemma, and also growth and expansion of T-tubes.

There is an increase in the number of intercalated discs, which are located at a distance of 3-4 sarcomeres from each other in the places of formation of lateral growth of the cytoplasm. The nuclei of many cardiomyocytes are large, polyploid. Diameter of the blood vessels supplying myocardium was dilated, which showed the improvement of the blood supply to the target organ influenced by the drug's calcium channel blocker. Number of mitochondria and their diameter grew. Thus, we can talk about the positive effect of this drug on the morphological state of the myocardium.

In the fourth experimental group, the striated structure of the muscle remained intact. Mitochondria were located mainly around the nucleus. Signs of hypertrophy where noted at the myocardium, however, along with this, there were destructive-dystrophic changes (increase in number of lysosomes, degeneration in cardiomyocytes, mitochondrial cristae clearly not differentiated) noted. It demonstrated the incomplete compensation in case of $\mathrm{AH}$ and the use of combined treatment.

\section{Conclusion}

1. Monotherapy with calcium channel blockers has a substantial positive effect on to the morphological condition of the myocardium of the left ventricle of animals with induced hypertension. 
2. Monotherapy with angiotensin converting enzyme inhibitors and combined effect of the above mentioned drugs did not have a positive impact on hypertrophy of the heart muscle.

\section{References}

[1] Факторы, влияющие на смертность от сердечно-сосудистых заболеваний в российской популяции./ [Шальнова С.А., Деев А.Д., Оганов Р.Г.] // Кардиоваск тер и проф. — 2005. — Т. 4, №1. —С. 4-9.

[2] Wolf-Maier K. Hypertension Prevalence and Blood Pressure Levels in European Countries, Canada, and the United States / Wolf-Maier K., Cooper R., Banegas J et al. // JAMA. — 2003. — Vol. 289. — P.2363-2369.

[3] Ong K.L. Prevalence, Awareness, Treatment, and Control of Hypertension Among United States Adults 1999-2004 / Ong K.L., Cheung B.M., Man Y.B. et al. // Hypertension. — 2007. — Vol. 49. — P.69-75.

[4] Altun B. Prevalence, awareness, treatment, and control of hypertension in Turkey (the PatenT study) in 2003 / Altun B., Arici M, Zoglu G. N. et al. // J. Hypertension. — 2005. — Vol. 23. — P.1817-1823.

[5] Bhatt D.L. International prevalence, recognition and treatment of cardiovascular risk factors in outpatients with atherothrombosis / Bhatt D.L., Steg P.G., Ohman E.M.

et al. // JAMA. — 2006. - Vol. 295 (2). -P.180-189.

[6] Оганов Р.Г. Смертность от сердечно-сосудистых и других хронических неинфекционных заболеваний среди трудоспособного населения России / Р.Г. Оганов, Г.Я. Масленникова // Кардиоваск тер и проф. — 2002. №3.

a. C.4-8.

[7] Шальнова С.А. Распространенность артериальной гипертонии в России. Информированность, лечение, контроль / С.А. Шальнова, А.Д. Деев, О.В. Вихирева и др. // Проф. забол и укреп здоровья. - 2001. №2.- C.3-7.

[8] Mancia G. Guidelines for the Management of Arterial Hypertension of the European Society of Hypertension (ESH) and of the European Society of Cardiology (ESC) / Mancia G., De Backer G.,Dominiczak A., et al. // J Hypertens. — 2007. - Vol.25-P.1105-1187.

[9] Диагностика и лечение артериальной гипертензии. Рекомендации Российского медицинского общества по артериальной гипертонии и Всероссийского научного общества кардиологов. М., 2008.

[10] Mancia G. Blood pressure control and risk of stroke in untreated and treated hypertensive patients screened from clinical practice: results of the For Life study / Mancia G., Ambrosioni E., Agabiti-Rosei E., et al. // J. Hypertension. - 2005. - P.1575-1581.

[11] Waeber B. Treatment strategy to control blood pressure optimal in hypertensive patients. / Waeber B. // Blood Pressure. - 2001. - Vol.10. - P.62-73.

[12] Сахарчук И.И. Коррекция нарушений эндотелиальной функции у больных гипертонической болезнью с помощью антигомотоксических препаратов / И.И. Сахарчук, Б.К. Шамугия, Н.Н. Сидорова, Е.И. Алексеенко // Лікар. справа. - 2002. - N 8. - С. 66-68.

[13] Запорожан В.М. Біоетика / В.М. Запорожан, М. Л. Аряєв. - К.: Здоров’я, 2005. — 288 с.

[14] Саркисов Д.С. Воспроизведение болезней человека в эксперименте / Д.С. Саркисов, П.И. Ремизов. - М., 1960. - $780 \mathrm{c}$.

[15] Рыболовлев Ю.Р Дозирование веществ для млекопитающих по константе биологической активности / Ю.Р. Рыболовлев, Р.С. Рыболовлев // Доклады АН СССР. - 1979. Т.247, №6, - С. 1513-1516.

[16] Дотримання етичних та законодавчих норм і вимог при виконанні наукових морфологічних досліджень: методичні рекомендації / [В.Л. Кулініченко, В.Д. Мішалов, Ю.Б. Чайковський та ін.]. — К., 2007. — 25 с.

[17] Гайер Г. Электронная гистохимия /Г.Гайер. - М.: Мир, 1974. — 217c. 